\title{
Traditional and Complementary Medicine Methods
}

\section{Which Have Become Widespread from The Perspective}

\section{of Family Physicians and self-Employed Pharmacists;}

\section{Approaches, Thoughts}

\author{
Nagihan Yildiz Çeltek, Ufuk Ünlü* \\ Department of Family Medicine, Tokat Gaziosmanpaşa University, Tokat, Turkey
}

\begin{abstract}
Traditional and complementary medicine, which has been defined by the World Health Organization as the whole of knowledge, skills, and practices based on different cultures specific theories, beliefs and experiences, are used in the protection of health through the diagnosis and treatment of physical and mental disorders, has become widespread in our society with the support of the ministry of health on the subject in recent ye ars. We aimed to evaluate the opinions of family physicians and freelance pharmacists working in the city center of Tokat regarding traditional medicine.

This cross-sectional study with free pharmacists and family physicians working in the city center of Tokat between 10.12.2019 and 20.12.2019. The data were obtained by a questionnaire, questioning the demographic information and the attitudes of the participants towards traditional treatment methods. Cross-tables and chi-square tests were used to evaluate qualitative variables. In the calculations, statistical software (SPSS Statistics 19) was used.

Regarding the participants, $41(48.8 \%)$ were men and $43(52.2 \%)$ were women. It was observed that there were $12(14.3 \%)$ family medicine specialists, 41 $(48.8 \%)$ general practitioners, 31 freelance pharmacists $(36.9 \%)$. The average age was $40.6(27-71)$. The rate of receiving traditional and complementary medicine practice training was found to be statistically significantly higher among pharmacists than physicians $(p<0.05)$. However $73.1 \%$ of participants who did not receive training stated that they wanted to receive education.

We would like to emphasize the importance and necessity of taking traditional and complementary medical education programs within the scope of inservice education programs.

Key Words: Traditional and complementary medicine, family physicians, pharmacists
\end{abstract}

\section{Introduction}

Traditional medicine, which is known as traditional health teachings and has no consensus on definition and applying methods in the world, is defined by the World Health Organization as the whole of skills and practices which based on different cultural-specific theories, beliefs and experiences used for the protection and treatment of physical and mental illnesses (1).

Traditional medicine methods are specific to cultures has been used today all over the world. A National Complementary and Alternative Medicine Center (NCCAM) was established in the United States in 1998 to integrate modern medicine by examining the reliability and effectiveness of traditional treatment methods (2). The Department of Traditional and Complementary Medicine Practices was established within the Ministry of Health in our country in 2012. A regulation defining titles such as traditional treatment practitioners, indications-contraindications was published on 27 October 2014 (3).
The use of traditional medicine has become increasingly common in our society in recent years with the support of the ministry of health on the subject. However, it is also possible that people with chronic diseases cause a delay in modern medical treatments, a decrease in the effectiveness of medications and/or an increase in side effects. On the other hand, the fact that the possibility of unauthorized people practicing traditional and complementary medicine methods to develop undesirable results is another risk factor (4). Studies on traditional medicine methods approaches of healthcare professionals are gradually increasing. In this study, we aimed to evaluate the opinions of family physicians and freelance pharmacists working in the city of Tokat regarding traditional medicine.

\section{Material and Methods}

Tokat Gaziosmanpaşa University Faculty of Medicine Ethics Committee approval was obtained for our cross-sectional study (19-KAEK-264). 69 free pharmacists and 68 family physicians who worked in 
Table 1. Distribution of variables by gender

\begin{tabular}{|c|c|c|c|c|}
\hline & & \multicolumn{2}{|c|}{ Gender } & \multirow{2}{*}{$\mathrm{p}$} \\
\hline & & Female n $(\%)$ & Male n $(\%)$ & \\
\hline \multirow{5}{*}{$\begin{array}{l}\text { Perspective on traditional and } \\
\text { complementary treatment methods }\end{array}$} & Averseness & $2(2,4)$ & $3(3,6)$ & \multirow{6}{*}{0,544} \\
\hline & Not Concern & $8 \quad(9,5)$ & $6 \quad(7,1)$ & \\
\hline & Advising & $16(19)$ & $10(11,9)$ & \\
\hline & $\begin{array}{l}\text { I would like to apply if I } \\
\text { receive training }\end{array}$ & $16(19)$ & $19(22,6)$ & \\
\hline & Applying & $1 \quad(1,2)$ & $3(3,6)$ & \\
\hline \multirow{4}{*}{$\begin{array}{l}\text { Questioning whether patients are using } \\
\text { traditional and complementary treatment } \\
\text { methods }\end{array}$} & Always & $0 \quad(0)$ & $1 \quad(1,2)$ & \\
\hline & Frequently & $11(13,1)$ & $5 \quad(6)$ & \multirow{3}{*}{0,171} \\
\hline & Rarely & $31(36,9)$ & $31(36,9)$ & \\
\hline & Never & $1 \quad(1,2)$ & $4 \quad(4,8)$ & \\
\hline \multirow{2}{*}{$\begin{array}{l}\text { information request from patients about } \\
\text { traditional medicine }\end{array}$} & Frequently & $13(15,5)$ & $16(19)$ & \multirow{2}{*}{0,380} \\
\hline & Rarely & $30(35,7)$ & $25(29,8)$ & \\
\hline \multirow{3}{*}{$\begin{array}{l}\text { Counseling patients about traditional and } \\
\text { complementary treatment methods }\end{array}$} & Frequently & $5 \quad(6)$ & $8 \quad(9,5)$ & \multirow{3}{*}{0,596} \\
\hline & Rarely & $25(29,8)$ & $21(25)$ & \\
\hline & Never & $13(15,5)$ & $12(14,3)$ & \\
\hline \multirow{2}{*}{$\begin{array}{l}\text { Training in traditional and complementary } \\
\text { treatment methods }\end{array}$} & Yes & $9 \quad(10,7)$ & $8(9,6)$ & \multirow{2}{*}{1} \\
\hline & No & $34(40,5)$ & $33(39,3)$ & \\
\hline \multirow{2}{*}{$\begin{array}{l}\text { Using traditional treatment for } \\
\text { herself/himself or a relative }\end{array}$} & Yes & $15(17,9)$ & $18(21,4)$ & \multirow{2}{*}{0,533} \\
\hline & No & $28(33,3)$ & $23(27,4)$ & \\
\hline
\end{tabular}

the city center of Tokat between 10.12.2019 20.12.2019 constituted the universe of our study. Those who could not be contacted during the working dates and did not agree to participate in our study were excluded from the study. Our study was conducted with 31 free pharmacists and 53 family physicians who agreed to participate in the study. The data were obtained face-to-face and by e-mail via a questionnaire questioning the demographic information prepared by us and the attitudes of the participants towards traditional treatment methods. Descriptive analyses were carried out to give information about the general characteristics of the working groups. Data on categorical variables were given as $\mathrm{n}$ and $(\%)$ while data of continuous variables were in the form of mean \pm standard deviation. Cross tables and chi-square tests were used to evaluate whether there is a relationship between qualitative variables. When $\mathrm{p}$ values are calculated less than 0.05 , it is considered statistically significant. Ready-made statistics software is used in calculations (IBM SPSS Statistics 19, SPSS inc., an IBM Co., Somers, NY).

\section{Results}

Regarding participants, 41 (48.8\%) were men and 43 $(52.2 \%)$ were women. Considering the distribution of occupational groups, it was observed that there were $12(14.3 \%)$ family medicine specialists, $41(48.8 \%)$ general practitioners, 31 free pharmacists $(36.9 \%)$. The mean age of the participants was 40.6 (27-71). When the variables questioned in the questionnaire were evaluated according to gender, there was no statistically significant difference. (Table 1)

The average working time of participants was 15.6 years. While the number of participants working 10 years or less was 26, the number of participants working for more than 10 years was 58 . According to working time it was seen that participants who were working for 10 years or less are more interested and willing about education even though there was no statistically significant difference among participants. Distribution of variables by working years are summarized in Table 2. (Table 2)

Regarding evaluation according to profession groups, there was no statistically significant difference in terms of their opinions about traditional and complementary methods applications. The most common methods which recommended and / or applied by participants were phytotherapy, acupuncture, and hijama (wet cup).

Considering all profession groups, participants answered the intensity of their patients' requests for information about traditional and complementary methods $34.5 \%$ as 'frequently'. In our study, the question that "Do you provide consultancy to patients on traditional and complementary methods" were answered with the answer 'none' and 'rarely' at 
Table 2. Distribution of variables by working years

\begin{tabular}{|c|c|c|c|c|}
\hline & & \multicolumn{2}{|c|}{ Working Years } & \multirow{2}{*}{$\mathrm{p}$} \\
\hline & & $\leq 10$ years & $>10$ Years & \\
\hline \multirow{5}{*}{$\begin{array}{l}\text { Perspective on traditional } \\
\text { and complementary } \\
\text { treatment methods }\end{array}$} & Averseness & $1(1,2)$ & $4 \quad(4,8)$ & \multirow{5}{*}{0,537} \\
\hline & Not Concern & $2(2,4)$ & $12(14,3)$ & \\
\hline & Advising & $9 \quad(10,7)$ & $17(20,2)$ & \\
\hline & $\begin{array}{l}\text { I would like to apply if } \\
\text { I receive training }\end{array}$ & $12(14,3)$ & $23(27,4)$ & \\
\hline & Applying & $2(2,4)$ & $2 \quad(2,4)$ & \\
\hline \multirow{3}{*}{$\begin{array}{l}\text { Counseling patients about } \\
\text { traditional and } \\
\text { complementary treatment } \\
\text { methods }\end{array}$} & Frequently & $5(6)$ & $8 \quad(9,5)$ & \multirow{3}{*}{0,774} \\
\hline & Rarely & $13(15,5)$ & $33(39,3)$ & \\
\hline & Never & $8(9,5)$ & $17(20,2)$ & \\
\hline \multirow{2}{*}{$\begin{array}{l}\text { Training in traditional and } \\
\text { complementary treatment } \\
\text { methods }\end{array}$} & Yes & $9 \quad(10,7)$ & $8(9,5)$ & \multirow{2}{*}{0,057} \\
\hline & No & $17(20,2)$ & $50(59,5)$ & \\
\hline \multirow{2}{*}{$\begin{array}{l}\text { Would you like to get it if } \\
\text { you have not been trained? } \\
\text { (n:67) }\end{array}$} & Yes & $14(20,9)$ & $35(52,2)$ & \multirow{2}{*}{0,057} \\
\hline & No & $3(4,5)$ & $15(22,4)$ & \\
\hline
\end{tabular}

Table 3. Data on traditional methods counselling

\begin{tabular}{llllll}
\hline $\begin{array}{l}\text { Do you consult your patients } \\
\text { about traditional methods? }\end{array}$ & $\begin{array}{l}\text { General } \\
\text { Practitioner }\end{array}$ & $\begin{array}{l}\text { Family Medicine } \\
\text { Specialist }\end{array}$ & Pharmacist & Total & $\mathrm{p}$ \\
\hline Never & 15 & 5 & 5 & $25(\% 29,8)$ & \\
Rarely & 21 & 6 & 19 & $46(\% 54,8)$ & 0,264 \\
Frequently & 5 & 1 & 7 & $13(\% 15,5)$ & \\
\hline
\end{tabular}

the rate of $84.5 \%$ (n: 71). (Table 3) As a reason for this situation, $60.7 \%$ of the participants stated that they did not give consultancy because they thought that they did not have a sufficient level of knowledge. Similarly, questioning patients' use of traditional and complementary methods was found to be low in all profession groups $(20.2 \%)$.

The rate of training of traditional and complementary treatment methods in pharmacists was statistically significantly high. $(p<0.005) 73.1 \%$ of participants who did not receive training (n: 67) stated that they wanted to get training. (Table 4)

Regarding evaluating of using the traditional and complementary treatment methods of the participants themselves and/or their relatives, there was no statistically significant difference between professional groups.

\section{Discussion}

Physicians and pharmacists in primary health care institutions in our health system are the firstly and most frequently visiting by patients in terms of health counselling. Patients who use traditional treatment methods which increasing variety and useable in our country refer primary health care institutions in order to consult about treatment applying. However, studies on the attitudes of the relevant healthcare professionals towards traditional treatment methods are not yet sufficient. In our study, in which we aimed to evaluate the views of family physicians and community pharmacists on traditional medicine about using, consulting, or applying we found that the participants had different opinions about traditional medicine. However, we observed that the participants felt themselves to have insufficient knowledge about the subject. The rate of receiving traditional and complementary medicine practice training was found to be statistically significantly higher among pharmacists than physicians $(p<0.05)$. The fact that 
Çeltek and Ünlü / Traditional and complementary medicine and doctors and pharmacist

Table 4. Data on traditional treatment methods training of participants

\begin{tabular}{lccccc}
\hline $\begin{array}{l}\text { Have you received traditional } \\
\text { treatments methods training? }\end{array}$ & $\begin{array}{c}\text { General } \\
\text { Practitioner }\end{array}$ & $\begin{array}{c}\text { Family Medicine } \\
\text { Specialist }\end{array}$ & Pharmacist & Total & $\mathrm{p}$ \\
\hline Yes & 2 & - & 15 & 17 & $<0,005$ \\
No & 39 & 12 & 16 & 67 & \\
Would you like to get training if & & & & & \\
you did not? & 28 & 9 & 12 & 49 & 0,958 \\
Yes & 11 & 3 & 4 & 18 & \\
No & & & &
\end{tabular}

$73.1 \%$ of participants who did not receive training stated that they wanted to receive education is remarkable.

Regarding examining in terms of gender and working years in our study, there was no statistically significant difference in thoughts and attitudes about traditional and complementary medicine methods. Although the negative thoughts of the participants whose working year is more than 10 years are higher than the participant group working 10 years or less; the desire to receive education in both groups stands out prominently. Considering similar studies, it is observed that the desire to get education increases with age and the physicians who work more than 10 years in the profession more frequently recommend traditional methods to their patients in the study of Bal (5). In the study of Tekçi (6) with the research assistant physicians, there was no significant relationship between the participants' age, gender and working years and the desire to receive traditional and complementary treatment methods education. In the study conducted by Elbi et al. (2) with family physicians, the rate of using traditional treatment methods by physicians who have 10 or more years of working time was found to be significantly higher than the participants who worked less time. In the literature, different results are observed in comparisons of working periods and traditional medicine approaches. The difference in this comparison result of our study can be explained by the fact that it was conducted in a single center.

Thinking about the attitudes of the participants regarding the traditional and complementary treatment methods, it is seen that $73.6 \%$ of the physicians and $83.8 \%$ of the pharmacists had positive thoughts in our study. However, many participants who thought positively stated that be worried about abuse of the traditional methods. In the study of Özçakır et al (7) it was showed that $51.4 \%$ of the participating physicians thought that traditional treatment methods were beneficial. In the study conducted by Elbi et al. (2) with family physicians, the rate of believing that traditional and complementary treatment methods are useful was found to be $60.3 \%$. The results of our study are consistent with the literature.

In our study, it has been shown that $77.4 \%$ of the participants recommend and/or apply traditional methods. The most common methods which recommended and/or applied by participants were phytotherapy, acupuncture, and hijama (wet cup). The rate of using the traditional methods of the participants themselves or their relatives was found to be $39.3 \%$ in our study. In the study of Bal (5), it was shown that $43.7 \%$ of the physicians have the desire to use complementary treatment methods in the treatment of patients and also preferred treatment methods differed among healthcare professionals who recommend, use, and apply traditional treatment methods. Lafç1 et al (8) stated that $25 \%$ of the participants used at least one of the complementary and alternative treatment methods, and herbal treatment and massage are the most frequently used treatment methods. The rate of recommending and/or applying traditional methods among participants is higher. This difference can be explained by the fact that our study was conducted in the recent past compared to other studies and the increase in awareness of traditional treatment methods.

The rate of $73.8 \%$ as 'rarely' and $6 \%$ as 'none' answers to question about questioning patients' use of the traditional treatment methods are remarkable. In our study, we found that patients demand information about traditional and complementary treatment methods. However, just $15.5 \%$ of the participants stated that they counsel patients 'frequently' about this topic. Participants who were not counselling stated the reason for this as "lack of information" most frequently. In our study, the rate of training of the participants regarding traditional and complementary treatment methods was $24.6 \%$. The rate of training in the pharmacist group was found to be statistically significantly higher than the physician group. $73.1 \%$ of the participants who have not training stated that they wanted to receive 
education of traditional treatment methods. In the study of Tekçi (6), one of the similar studies on the subject, it was shown that $67 \%$ of the physicians recommended traditional treatment methods to their patients. $83.5 \%$ of physicians thought positively in terms of including traditional treatment methods in medical education. In a different study, it has been shown that patients do not demand information and share their use of traditional and complementary treatments methods with their doctors because of the fear of condemnation by doctors and the idea that doctors will not know and not care about it (9). Literature data support the results of our study about the participants' desire to receive education and consulting patients.

We tried to evaluate the opinions of family physicians and freelance pharmacists working in primary care regarding traditional and complementary medicine practices, which have become increasingly common in our country recently as in whole the world. In our study, we found those pharmacist participants received a higher rate of traditional and complementary treatment methods training than physicians. However, non-training participants in both physicians and pharmacists group found themselves insufficient on the subject and wanted to receive training due to lack of knowledge. We would like to emphasize the importance and necessity of including into service training programs of traditional treatment methods. Due to the importance of the subject in terms of public health, higher participation and comprehensive studies are needed.

\section{References}

1. World Health Organization. General guidelines for methodologies on research and evaluation of traditional medicine. Geneva: World Health Organization, 2000.

2. Elbi H, Nazik F, Balcı UG, Çölbe N, Öngel K. Attitudes of a group of family physicians on complementary and alternative treatments, Turkish Journal of Family Medicine \& Primary Care 2015; 9: 170-175.

3. Şahin S. Geleneksel, tamamlayıc1, alternatif tıp uygulamalarına genel bir bakış, Türk Aile Hek Derg 2017; 21: 159-162.

4. Oral B, Öztürk A, Balcı E, Sevinç N, Aile sağlığ1 merkezine başvuranların geleneksel /alternatif tıpla ilgili görüşleri ve kullanım durumu, TAF Prev Med Bull 2016; 15: 75-82.

5. Bal B. Hemşire ve hekimlerin tamamlayıc1 ve alternatif tedavilere ilişkin görüşleri. Yüksek Lisans Tezi, Hacettepe Üniversitesi Sağlik Bilimleri Enstitüsü İç Hastalıkları Hemşireliği Program1 2009; 34-53.

6. Tekçi A. Araştırma görevlisi hekimlerin geleneksel, tamamlayıc1 ve alternatif tip uygulamaları ile ilgili bilgi ve tutumları, Tipta uzmanlık tezi, Dicle Üniversitesi Tip Fakültesi Aile Hekimliği Anabilim Dalı 2017; 43-60.

7. Özçakır A, Sadıkoglu G, Bayram N, Mazıcıoğlu MM, Bilgel N, Beyhan I. Turkish general practitioners and complementary/alternative medicine. The Journal of Alternative and Complementary Medicine 2007; 13: 1007-1010.

8. Lafçı D, Kaşıç̧ı MK. Yataklı sağlık kuruluşunda görev yapan sağlık personelinin tamamlayıcı ve alternatif tedavi yöntemlerini bilme ve kullanma durumları. Gümüşhane Üniversitesi Sağlık Bilimleri Dergisi 2014; 3: 1-18.

9. Renzi C, Mastroein S, Paradisi M, Mazzotti E, Pasquini P. Complementary and alternative medicine: knowledge and attitudes among dermatologists. Acto Derm Venereol 2009; 89: 642-644. 